\title{
Smoking, white blood cell counts, and TNF system activity in Japanese male subjects with normal glucose tolerance
}

\author{
Naoya Watanabe ${ }^{1}$, Mitsuo Fukushima ${ }^{2 *}$, Ataru Taniguchi ${ }^{3}$, Takahide Okumura ${ }^{4}$, Yoshio Nomura $^{5}$, \\ Fusanori Nishimura ${ }^{6}$, Sae Aoyama ${ }^{2}$, Daisuke Yabe ${ }^{7}$, Yoshio Izumi $^{8}$, Ryoichi Ohtsubo ${ }^{7}$, Yoshikatsu Nakai ${ }^{9}$ and \\ Shoichiro Nagasaka ${ }^{10}$
}

\begin{abstract}
Background: Cigarette smokers have increased white blood cell (WBC) counts and the activation of tumor necrosis factor (TNF). The effect of smoking on WBC counts and TNF system activity, however, has not been separately investigated yet.
\end{abstract}

Subjects and Methods: One hundred and forty-two Japanese male subjects with normal glucose tolerance were recruited. They were stratified into two groups based on the questionnaire for smoking: one with current smokers $(n=48)$ and the other with current non-smokers $(n=94)$. Whereas no significant differences were observed in age, BMI, high molecular weight (HMW) adiponectin, and TNF- $\alpha$ between the two groups, current smokers had significantly higher soluble TNF receptor 1 (sTNF-R1) $(1203 \pm 30$ vs. $1116 \pm 21 \mathrm{pg} / \mathrm{ml}, p=0.010)$ and increased WBC counts (7165 \pm 242 vs. $5590 \pm 163 / \mu \mathrm{l}, p<0.001)$ and lower HDL cholesterol $(55 \pm 2$ vs. $60 \pm 1 \mathrm{mg} / \mathrm{dl}, p=$ $0.031)$ as compared to current non-smokers. Next, we classified 48 current smokers into two subpopulations: one with heavy smoking (Brinkman index $\geq 600$ ) and the other with light smoking (Brinkman index $<600$ ).

Results: Whereas no significant difference was observed in age, BMI, HMW adiponectin, WBC counts and TNF- $\alpha$, STNF-R1 and sTNF-R2 were significantly higher in heavy smoking group (1307 $\pm 44 \mathrm{vs.} 1099 \pm 30 \mathrm{pg} / \mathrm{ml}, p<0.001$; $2166 \pm 86$ vs. $827 \pm 62 \mathrm{pg} / \mathrm{ml}, p=0.005)$ than in light smoking group, whose sTNF-R1 and sTNF-R2 were similar to non-smokers (sTNF-R1: $1116 \pm 15 \mathrm{pg} / \mathrm{ml}, p=0.718$, sTNF-R2; $1901 \pm 32 \mathrm{pg} / \mathrm{ml}, p=0.437$ ). In contrast, WBC counts were significantly increased in heavy $(7500 \pm 324 / \mu \mathrm{l}, p<0.001)$ or light $(6829 \pm 352 / \mu \mathrm{l}, p=0.001)$ smoking group as compared to non-smokers (5590 $\pm 178 / \mu l)$. There was no significant difference in WBC counts between heavy and light smoking group $(p=0.158)$.

Conclusion: We can hypothesize that light smoking is associated with an increase in WBC counts, while heavy smoking is responsible for TNF activation in Japanese male subjects with normal glucose tolerance.

\section{Background}

It is well recognized that smoking is one of the most important factors contributing to the evolution of atherosclerosis and chronic obstructive pulmonary disease in humans $[1,2]$. It is well established that current smokers are characterized by increased white blood cell (WBC) counts and increased tumor necrosis factor- $\alpha$ (TNF- $\alpha)$

\footnotetext{
* Correspondence: fukushima7788@yahoo.co.jp

${ }^{2}$ Division of Clinical Nutrition and Internal Medicine, Okayama Prefectural University, 111, Kuboki, Soja-city, Okayama, 719-1197, Japan

Full list of author information is available at the end of the article
}

$[3,4]$. However, the effects of smoking on the increase in WBC counts and TNF- $\alpha$ have not been separately investigated yet. In this regard, a major problem is that compared with circulating TNF- $\alpha$, soluble TNF receptor (soluble TNF receptor 1 (sTNF-R1) and soluble TNF receptor 2 (sTNF-R2)) levels remain elevated for longer periods of time and are of more value for monitoring TNF system activities. Another problem is that the degree of glucose tolerance or of body mass index per se is considered to affect WBC counts and TNF system activity in man. To overcome these difficulties, we

\section{Biomed Central}


recruited the subjects with normal glucose tolerance whose BMI is less than $29.0 \mathrm{~kg} / \mathrm{m}^{2}$ and measured soluble TNF receptors along with TNF- $\alpha$.

\section{Subjects and Methods Participants and Setting}

A total of 142 Japanese male subjects with normal glucose tolerance who visited Yodogawa Christian Hospital for the medical checkup were enrolled for the present study after the ethics committee of Yodogawa Christian Hospital approved the protocol and informed written consents were obtained from every participant. Body mass index in these subjects was $23.2 \pm 0.2 \mathrm{~kg} / \mathrm{m}^{2}$ (mean $\pm \mathrm{SEM}$ ). Exclusion criteria were cancer, ischemic heart disease, cerebral stroke, renal disease, hepatic disease, asthma, or any inflammatory disease such as rheumatoid arthritis or inflammatory bowel disease. Six (4\%) of the 142 subjects were treated with antihypertensive medications. Twelve (8\%) of the 142 subjects were treated with lipid lowering agents. No subjects have received any medications known to alter glucose tolerance. Before the study, they did not use anti-inflammatory medication. All subjects had ingested at least $150 \mathrm{~g}$ of carbohydrate for the 3 consecutive days preceding the study. They did not consume alcohol or perform heavy exercise for at least one week before the study.

\section{Definitions of Active Smoking}

Smokers and non-smokers were determined based on the questionnaire for smoking. Smokers were further classified into two subgroups based on the value of Brinkman index; one with heavy smoking (Brinkman index $\geqq 600$ ) and the other with light smoking (Brinkman index $<600$ ). Brinkman index was calculated as the product of the number of tobacco smoked and inhaled year [5]. Miyatake et al. [6] recently demonstrated that the subjects with a Brinkman index $\geqq 600$ are at increased risk for metabolic syndrome as compared to those with a Brinkman index less than 600 in Japanese men.

\section{Blood Analysis}

Blood was drawn from the antecubital vein in the morning after a 12-hour fast. Plasma glucose, triglyceride, total cholesterol, HDL cholesterol, LDL cholesterol, white blood cell counts, serum creatinine, and hemoglobin A1c were measured. Hemoglobin A1c (HbA1c) was shown in NGSP values as recommended by the Japan Diabetes Society $[7,8]$. Along with TNF- $\alpha$, soluble TNF receptors (sTNF-R1, sTNF-R2) were measured in the present study. Serum TNF- $\alpha$ concentrations were measured by enzyme immunoassay kit (Quantikine HS Human TNF- $\alpha$ immunoassay kit, R\&D systems. Inc, Minneapolis, MN, USA) and serum concentrations of
sTNF-R1 and sTNF-R2 were measured by enzymelinked immunosorbent assay (ELISA) (BIOTRAK, Amersham Life Sciences, Uppsala, Sweden), as described previously [9-12]. The limits of sensitivity for TNF- $\alpha$, sTNF-R1 and sTNF-R2 were $0.5 \mathrm{pg} / \mathrm{ml}, 25 \mathrm{pg} / \mathrm{ml}$ and $50 \mathrm{pg} / \mathrm{ml}$, respectively. The intra-assay and interassay coefficients of variation were less than $8 \%$ for TNF- $\alpha$, sTNF-R1 and sTNF-R2. Insulin and high molecular weight adiponectin (HMW adiponectin) were measured as described previously $[11,13]$. Samples for TNF, insulin, and HMW adiponectin were prepared, frozen, and stored at $-70^{\circ} \mathrm{C}$ until the assay. The estimate of insulin resistance by HOMA (HOMA-IR) was calculated with the formula: fasting serum insulin $(\mu \mathrm{U} / \mathrm{ml}) \times$ fasting glucose $(\mathrm{mmol} / \mathrm{l}) / 22.5$ [14]. We previously demonstrated that HOMA-IR is strongly correlated with minimal model derived insulin sensitivity in Japanese subjects with varying degrees of glucose tolerance [15]. Body fat percentage was measured using bioelectrical impedence method.

\section{Statistical Analysis}

Data were presented as means \pm SEM. Statistical analyses were conducted using the StatView 5 system (Statview, Berkeley, CA). The differences between smokers and non-smokers were analyzed by Student's t-test. When more than two groups were compared, the significance of differences between any two groups was determined using Bonferroni's multiple range test. $p<0.05$ was considered significant.

\section{Results}

Table 1 shows the clinical profiles in the subjects studied. They were all Japanese males with normal glucose tolerance. They were divided into two groups based on the questionnaire for smoking; one with current smokers $(n=48)$ and the other with current non-smokers $(\mathrm{n}=94)$. There was no significant difference in age $(51.5 \pm 1.2$ vs $52.5 \pm 1.0 \mathrm{yr}, p=0.286)$, BMI $(23.1 \pm 0.4$ vs $23.2 \pm 0.2 \mathrm{~kg} / \mathrm{m}^{2}, p=0.389$ ), waist circumference $(84.5 \pm 1.0$ vs $83.8 \pm 0.7 \mathrm{~cm}, p=0.286)$, body fat percentage ( $21.2 \pm 0.7$ vs $20.6 \pm 0.4 \%, p=0.217)$, systolic (119 \pm 2 vs $122 \pm 1 \mathrm{mmHg}, p=0.077)$ and diastolic (75 \pm 1 vs $75 \pm 1 \mathrm{mmHg}, p=0.481)$ blood pressure, fasting glucose (95 \pm 1 vs $95 \pm 1 \mathrm{mmHg}, p=0.473)$, HbA1c ( $5.12 \pm 0.04$ vs $5.15 \pm 0.03 \%, p=0.250)$, fasting insulin $(3.8 \pm 0.3$ vs $3.9 \pm 0.2 \mu \mathrm{U} / \mathrm{ml}, p=0.408)$, HOMA-IR $(0.88 \pm 0.08$ vs $0.90 \pm 0.05, p=0.403)$, total cholesterol (199 \pm 5 vs $204 \pm 3 \mathrm{mg} / \mathrm{dl}, p=0.190)$, triglyceride (130 \pm 11 vs $121 \pm 4 \mathrm{mg} / \mathrm{dl}, p=0.328)$, and LDL cholesterol $(116 \pm 5 \mathrm{vs} 117 \pm 3 \mathrm{mg} / \mathrm{dl}, p=0.437)$ between the two groups. Although 2 hour glucose concentration after 75 g oral glucose load was similar between smokers and non-smokers $(115 \pm 2$ vs $112 \pm 2 \mathrm{mg} / \mathrm{dl}, p=0.158)$, 
Table 1 Clinical characteristics of the 142 male subjects studied.

\begin{tabular}{cc}
\hline age $(\mathrm{yr})$ & $52.1 \pm 0.8$ \\
\hline body mass index $\left(\mathrm{kg} / \mathrm{m}^{2}\right)$ & $23.2 \pm 0.2$ \\
\hline waist circumference $(\mathrm{cm})$ & $84.0 \pm 0.6$ \\
\hline body fat percentage $(\%)$ & $20.8 \pm 0.4$ \\
\hline systolic blood pressure $(\mathrm{mmHg})$ & $121 \pm 1$ \\
\hline diastolic blood pressure $(\mathrm{mmHg})$ & $75 \pm 1$ \\
\hline fasting glucose $(\mathrm{mg} / \mathrm{dl})$ & $95 \pm 1$ \\
\hline 2 hr glucose after OGTT $(\mathrm{mg} / \mathrm{dl})$ & $113 \pm 5$ \\
\hline HbA1c $(\%)$ & $5.14 \pm 0.02$ \\
\hline total cholesterol $(\mathrm{mg} / \mathrm{dl})$ & $202 \pm 3$ \\
\hline triglyceride $(\mathrm{mg} / \mathrm{dl})$ & $124 \pm 10$ \\
\hline HDL cholesterol $(\mathrm{mg} / \mathrm{dl})$ & $59 \pm 1$ \\
\hline LDL cholesterol $(\mathrm{mg} / \mathrm{dl})$ & $117 \pm 3$ \\
\hline serum creatinine $(\mathrm{mg} / \mathrm{dl})$ & $0.80 \pm 0.01$ \\
\hline insulin $(\mu \mathrm{U} / \mathrm{ml})$ & $3.82 \pm 0.18$ \\
\hline HOMA-IR & $0.90 \pm 0.18$ \\
\hline TNF- $\alpha(\mathrm{pg} / \mathrm{ml})$ & $1.53 \pm 0.08$ \\
\hline sTNF-R1 $(\mathrm{pg} / \mathrm{ml})$ & $1145 \pm 180$ \\
\hline sTNF-R2 $(\mathrm{pg} / \mathrm{ml})$ & $1933 \pm 356$ \\
\hline HMW adiponectin $(\mu \mathrm{g} / \mathrm{ml})$ & $5.5 \pm 0.3$ \\
\hline WBC $(/ \mu \mathrm{l})$ & $6123 \pm 151$ \\
\hline
\end{tabular}

Values represent mean \pm SEM.

HDL cholesterol was significantly lower in smokers than in non-smokers $(55 \pm 2$ vs $60 \pm 1 \mathrm{mg} / \mathrm{dl}, p=0.031)$. Whereas TNF- $\alpha(1.64 \pm 0.15$ vs $1.47 \pm 0.09 \mathrm{pg} / \mathrm{ml}, p=$ $0.161)$ and sTNF-R2(1997 \pm 58 vs $1901 \pm 45 \mathrm{pg} / \mathrm{ml}, p=$ 0.102 ) were not significantly different between the two groups, sTNF-R1 $(1203 \pm 30$ vs $1116 \pm 22 \mathrm{pg} / \mathrm{ml}, p=$ $0.010)$ and WBC counts $(7165 \pm 242$ vs $5590 \pm 168 / \mu \mathrm{l}$, $p<0.001)$ were significantly higher in smokers than in non-smokers. No significant difference was observed in HMW adiponectin $(5.6 \pm 0.6$ vs $5.4 \pm 0.4 \mu \mathrm{g} / \mathrm{ml}, p=$ 0.358 ) between the two groups.

Our present study showed that there was a wide variation in Brinkman index in 48 current smokers (range, 100 to 1840). We therefore classified 48 current smokers into two groups based on the value of Brinkman index: one with heavy smoking (Brinkman index $\geqq 600$ ) and the other with light smoking (Brinkman index $<600$ ) (Table 2).

The subpopulations did not differ with respect to age, BMI, waist circumference, body fat percentage, systolic and diastolic blood pressure, fasting glucose, HbA1c, serum creatinine, lipid profile, HOMA-IR, and HMW adiponectin. Whereas no significant difference was observed in WBC counts and TNF- $\alpha$, sTNF-R1 and sTNF-R2 were significantly higher in heavy smoking group than in light smoking group, whose sTNF-R1 and sTNF-R2 were similar to those of non-smokers. In contrast, WBC counts were significantly higher in heavy or light smoking group as compared to non-smokers. There was, however, no significant difference in WBC counts between the two smoking groups.

Finally, we compared WBC counts and TNF system activities taking into account the inhaled year and the number of tobacco smoked. Inhaled year did not significantly affect WBC counts or TNF system activities in smokers (data not shown). In contrast, the number of tobacco smoked differently affected WBC and TNF in smokers (Table 3). Irrespective of the number of tobacco smoked, WBC counts were significantly higher in smokers as compared to non-smokers. However, no significant difference was observed in WBC counts between smokers who smoked $<20$ cigarettes per day and those who smoked $\geqq 20$ cigarettes per day. On the other hand, TNF system activities (sTNF-R1, sTNF-R2) were not statistically significant between non-smokers and current smokers who smoked $<20$ cigarettes per day, but they were significantly higher in current smokers who smoked $\geqq 20$ cigarettes per day as compared to those who smoked $<20$ cigarettes per day or to nonsmokers.

\section{Discussion}

In the present study, we confirmed that not only white blood cell (WBC) counts but also tumor necrosis factor (TNF) system activities are increased in current smokers when compared with current non-smokers. However, smoking affected differently on WBC counts and TNF system activities. Light smoking was associated with WBC counts, while heavy smoking was associated with TNF system activities.

As an index of active smoking, we used Brinckman index in the current study. Brinkman index is calculated as the product of the number of tobacco smoked and the inhaled year. Thus, it is not clear whether which of the two variables is responsible for the increase in WBC counts or the activation in TNF system in smokers. We therefore compared WBC counts and TNF system activities taking into account the inhaled year and the number of tobacco smoked. Inhaled year did not significantly affect WBC counts or TNF system activities in smokers. In contrast, the number of tobacco smoked differently affected WBC and TNF system in smokers (Table 3). Thus, the number of tobacco smoked per se seems to be independently responsible for the increase in WBC counts and TNF activation in our current smokers.

The reason why heavy smoking is associated with TNF system activity is not known, but it may suggest that the smoke-induced activation of TNF system 
Table 2 Clinical characteristics in non-smokers and smokers.

\begin{tabular}{|c|c|c|c|}
\hline & \multirow[t]{2}{*}{ non-smokers } & \multicolumn{2}{|c|}{ smokers } \\
\hline & & light smoking & heavy smoking \\
\hline number of subjects & 94 & 24 & 24 \\
\hline Brinkman index & 0 & $385 \pm 27^{\mathrm{A}}$ & $914 \pm 59^{\mathrm{AB}}$ \\
\hline number of tobacco smoked per day & 0 & $15.2 \pm 0.9^{\mathrm{A}}$ & $28.3 \pm 1.4^{\mathrm{AB}}$ \\
\hline inhaled year (yr) & 0 & $25.8 \pm 1.4^{\mathrm{A}}$ & $32.6 \pm 1.4^{\mathrm{AB}}$ \\
\hline age (yr) & $52.5 \pm 1.0$ & $49.3 \pm 1.7$ & $53.8 \pm 1.5$ \\
\hline body mass index $\left(\mathrm{kg} / \mathrm{m}^{2}\right)$ & $23.2 \pm 0.2$ & $22.8 \pm 0.6$ & $23.3 \pm 0.5$ \\
\hline body fat percentage (\%) & $20.6 \pm 0.4$ & $20.8 \pm 1.0$ & $21.6 \pm 1.0$ \\
\hline waist circumference $(\mathrm{cm})$ & $83.8 \pm 0.7$ & $84.1 \pm 1.4$ & $84.9 \pm 1.5$ \\
\hline systolic blood pressure $(\mathrm{mmHg})$ & $122 \pm 1$ & $120 \pm 3$ & $117 \pm 2$ \\
\hline diastolic blood pressure $(\mathrm{mmHg})$ & $75 \pm 1$ & $76 \pm 2$ & $74 \pm 2$ \\
\hline fasting glucose (mg/dl) & $95 \pm 1$ & $97 \pm 1$ & $92 \pm 1$ \\
\hline 2 hr glucose after OGTT (mg/dl) & $112 \pm 2$ & $115 \pm 4$ & $116 \pm 3$ \\
\hline $\mathrm{HbA1c}(\%)$ & $5.15 \pm 0.03$ & $5.10 \pm 0.05$ & $5.14 \pm 0.06$ \\
\hline total cholesterol (mg/dl) & $204 \pm 3$ & $193 \pm 7$ & $205 \pm 7$ \\
\hline triglyceride $(\mathrm{mg} / \mathrm{dl})$ & $121 \pm 14$ & $138 \pm 18$ & $123 \pm 13$ \\
\hline HDL cholesterol (mg/dl) & $60 \pm 1$ & $57 \pm 3$ & $54 \pm 3$ \\
\hline LDL cholesterol (mg/dl) & $117 \pm 3$ & $109 \pm 7$ & $124 \pm 7$ \\
\hline serum creatinine $(\mathrm{mg} / \mathrm{dl})$ & $0.81 \pm 0.01$ & $0.81 \pm 0.01$ & $0.79 \pm 0.02$ \\
\hline insulin $(\mu \mathrm{U} / \mathrm{ml})$ & $3.8 \pm 0.2$ & $3.5 \pm 0.4$ & $4.1 \pm 0.6$ \\
\hline HOMA-IR & $0.90 \pm 0.05$ & $0.83 \pm 0.09$ & $0.93 \pm 0.13$ \\
\hline TNF-a (pg/ml) & $1.47 \pm 0.09$ & $1.82 \pm 0.28$ & $1.46 \pm 0.11$ \\
\hline sTNF-R1 $(p g / m l)$ & $1116 \pm 21$ & $1099 \pm 30$ & $1307 \pm 44^{\mathrm{AB}}$ \\
\hline sTNF-R2 (pg/ml) & $1901 \pm 44$ & $1827 \pm 62$ & $2166 \pm 86^{A B}$ \\
\hline HMW adiponectin $(\mu \mathrm{g} / \mathrm{ml})$ & $10.7 \pm 0.8$ & $11.4 \pm 1.7$ & $11.1 \pm 1.5$ \\
\hline leptin $(\mathrm{ng} / \mathrm{ml})$ & $25.6 \pm 1.4$ & $23.2 \pm 2.0$ & $24.5 \pm 2.4$ \\
\hline WBC $(/ \mu \mathrm{l})$ & $5590 \pm 163$ & $6829 \pm 352^{\mathrm{A}}$ & $7500 \pm 324^{A}$ \\
\hline
\end{tabular}

(light smoking \& heavy smoking) Values represent mean \pm SEM.

${ }^{A}: p<0.01$ (vs. non-smokers) ${ }^{B}: p<0.01$ (vs. light smoking)

usually requires a significant amount of smoke exposure. This idea is supported from the observation shown by Zoppini et al. [16] that a marked increase of TNF- $\alpha$ system activation was observed with an increase in the number of cigarettes smoked.

Of particular note in the present study is that these findings were obtained after taking into account some variables including BMI, waist circumference, body fat percentage, blood glucose, HbA1c, and HMW adiponectin which are considered to affect TNF system activities and/or WBC counts $[17,18]$. It may be argued that smoking is associated with visceral fat accumulation. It seems, however, unlikely since Komiya et al. [19] did not fail to draw a conclusion that smoking is a strong and an independent risk factor for inducing excessive accumulation of visceral fat to a greater extent than sedentary life style or heavy alcohol consumption in Japanese men.

The mechanisms by which smokers have an increase in sTNF-R1 are not known at present. The possible explanation is that smoking exerts an inflammatory stimulus on macrophage which causes the release of TNF$\alpha$. One of the major organs contributing to the production of TNF may be the pulmonary alveolar cells. Another organ might be periodontal tissue. It is reported that TNF- $\alpha$ content of the gingival crevicular fluid from smokers is reported to be significantly increased as compared with non-smokers [20]. Whereas we did not check the status of periodontal disease in the subjects studied, we previously demonstrated that sTNF-R1 serum levels were independently associated with the severity of periodontal disease in Japanese subjects [21]. In addition, our team previously reported that the therapy of periodontal disease leads to the reduction in TNF- $\alpha$ in Japanese subjects [22].

It may be argued that adipose tissue might be another organ responsible for the increased TNF system activity in smokers. It seems, however, unlikely, since mean BMI in our subjects was $23.2 \mathrm{~kg} / \mathrm{m}^{2}$. In vitro study shown by 
Table 3 Clinical characteristics in non-smokers and smokers

\begin{tabular}{|c|c|c|c|}
\hline & \multirow{2}{*}{$\begin{array}{c}\text { non- } \\
\text { smokers }\end{array}$} & \multicolumn{2}{|c|}{ smokers } \\
\hline & & $\begin{array}{c}\text { light } \\
\text { smoking }\end{array}$ & $\begin{array}{c}\text { heavy } \\
\text { smoking }\end{array}$ \\
\hline number of subjects & 94 & 24 & 24 \\
\hline number of cigarettes a day & 0 & $12.3 \pm 0.8^{A}$ & $26.1 \pm 1.2^{\mathrm{AB}}$ \\
\hline inhaled year (yr) & 0 & $27.8 \pm 2.0^{\mathrm{A}}$ & $29.8 \pm 1.3^{\mathrm{A}}$ \\
\hline Brinkman index & 0 & $348 \pm 37^{A}$ & $786 \pm 59^{A B}$ \\
\hline age (yr) & $52.5 \pm 1.0$ & $52.5 \pm 1.9$ & $51.1 \pm 1.5$ \\
\hline body mass index $\left(\mathrm{kg} / \mathrm{m}^{2}\right)$ & $23.2 \pm 0.2$ & $22.2 \pm 0.7$ & $23.5 \pm 04$ \\
\hline waist circumference $(\mathrm{cm})$ & $83.8 \pm 0.7$ & $82.6 \pm 1.7$ & $85.3 \pm 1.3$ \\
\hline body fat percentage (\%) & $20.6 \pm 0.4$ & $19.7 \pm 1.4$ & $21.9 \pm 0.7$ \\
\hline $\begin{array}{c}\text { systolic blood pressure } \\
(\mathrm{mmHg})\end{array}$ & $122 \pm 1$ & $120 \pm 3$ & $118 \pm 2$ \\
\hline $\begin{array}{c}\text { diastolic blood pressure } \\
(\mathrm{mmHg})\end{array}$ & $75 \pm 1$ & $75 \pm 2$ & $75 \pm 2$ \\
\hline fasting glucose $(\mathrm{mg} / \mathrm{dl})$ & $95 \pm 1$ & $95 \pm 2$ & $94 \pm 1$ \\
\hline $\begin{array}{c}2 \text { hr glucose after OGTT } \\
(\mathrm{mg} / \mathrm{dl})\end{array}$ & $112 \pm 2$ & $114 \pm 5$ & $116 \pm 3$ \\
\hline $\mathrm{HbA1c}(\%)$ & $5.15 \pm 0.03$ & $5.09 \pm 0.07$ & $5.14 \pm 0.04$ \\
\hline total cholesterol (mg/dl) & $204 \pm 3$ & $198 \pm 8$ & $200 \pm 6$ \\
\hline triglyceride $(\mathrm{mg} / \mathrm{dl})$ & $121 \pm 14$ & $140 \pm 20$ & $126 \pm 13$ \\
\hline HDL cholesterol (mg/dl) & $60 \pm 1$ & $55 \pm 4$ & $56 \pm 3$ \\
\hline LDL cholesterol (mg/dl) & $117 \pm 3$ & $116 \pm 7$ & $117 \pm 7$ \\
\hline serum creatinine $(\mathrm{mg} / \mathrm{dl})$ & $0.81 \pm 0.01$ & $0.78 \pm 0.04$ & $0.78 \pm 0.02$ \\
\hline insulin $(\mu \mathrm{U} / \mathrm{ml})$ & $3.9 \pm 0.2$ & $3.2 \pm 0.5$ & $4.0 \pm 0.4$ \\
\hline HOMA-IR & $0.90 \pm 0.05$ & $0.77 \pm 0.13$ & $0.93 \pm 0.10$ \\
\hline TNF-a (pg/ml) & $1.47 \pm 0.09$ & $2.00 \pm 0.45$ & $1.47 \pm 0.09$ \\
\hline sTNF-R1 (pg/ml) & $1116 \pm 22$ & $1072 \pm 37$ & $1263 \pm 36^{\mathrm{AB}}$ \\
\hline sTNF-R2 (pg/ml) & $1901 \pm 45$ & $1767 \pm 80$ & $2101 \pm 70^{\mathrm{ab}}$ \\
\hline HMW adiponectin $(\mu \mathrm{g} / \mathrm{ml})$ & $10.7 \pm 0.8$ & $12.8 \pm 2.2$ & $10.5 \pm 1.3$ \\
\hline leptin (ng/ml) & $25.6 \pm 1.4$ & $20.9 \pm 2.3$ & $25.2 \pm 2.0$ \\
\hline $\mathrm{WBC}(/ \mu \mathrm{l})$ & $5590 \pm 168$ & $6687 \pm 396^{a}$ & $7382 \pm 298^{\mathrm{A}}$ \\
\hline
\end{tabular}

(light smoking \& heavy smoking) Values represent mean \pm SEM.

${ }^{A}: p<0.01$ (vs. non-smokers) ${ }^{B}: p<0.01$ (vs. light smoking)

${ }^{\mathrm{a}}: p<0.05$ (vs. non-smokers) ${ }^{\mathrm{b}}: p<0.05$ (vs. light smoking)

Kern et al. [23] disclosed that adipose tissue in the subjects with a BMI greater than $30 \mathrm{~kg} / \mathrm{m}^{2}$ released more TNF than those with a BMI less than $25 \mathrm{~kg} / \mathrm{m}^{2}$.

Whereas the contributory factors underlying tobaccoinduced atherosclerosis in humans remain to be elucidated, our present study might suggest that sTNF-R1 could become one of the candidates responsible for tobacco-induced atherosclerosis in humans. Rauchhaus et al. [24] disclosed that sTNF-R1 is predictive of cardiovascular mortality in patients with chronic heart failure. Our team demonstrated that sTNF-R1 is associated with albuminuria or serum homocysteine in Japanese type 2 diabetic patients $[10,25]$. Not only albuminuria but also serum homocysteine are known to be responsible for the development of atherosclerosis in man. Pinto-Sietsma et al. reported that smoking is related to albuminuria in humans [26]. Jatoi et al. [27] showed a significant linear relationship between smoking status and pulse wave velocity in man. We previously found that TNF system activities are independently associated with pulse wave velocity in non-obese Japanese type 2 diabetic patients [12].

\section{Conclusions}

In summary, it can be concluded that smoking is associated with increased WBC counts and increased activity of the TNF system, but the effect of smoking on WBC counts and TNF system activity was different in Japanese male subjects with normal glucose tolerance. Light smoking was associated with an increase in WBC counts, while heavy smoking was responsible for TNF activation in Japanese male subjects with normal glucose tolerance.

\section{Abbreviations}

WBC: White Blood cell; TNF: tumor necrosis factor; BMI: body mass index; HMW: high molecular weight; sTNF-R: soluble TNF receptor; HOMA-IR: homeostasis model assessment-insulin resistance

\section{Acknowledgements}

This research was supported by the Leading Project of Biosimulation, and Kobe Translational Research Cluster, the Knowledge Cluster Initiative from the Ministry of Education, Culture, Sports, Science and Technology, Japan. We thank Japanese Diabetes Society, Manpei Suzuki Diabetes Foundation, Use Techno Corporation, Ono Pharmaceutical Co.Ltd., Abbott Japan Co.Ltd. Dainippon Sumitomo Pharma Co.Ltd., for their help in this study.

\section{Author details}

'Health Care and Promotion Center, Yodogawa Christian Hospital, 2-9-26, Awaji, Higashiyodogawa-ku, Osaka, 533-0032, Japan. ${ }^{2}$ Division of Clinical Nutrition and Internal Medicine, Okayama Prefectural University, 111, Kuboki, Soja-city, Okayama, 719-1197, Japan. ${ }^{3}$ Division of Diabetes and Endocrinology, Kyoto Preventive Medical Center, 28, Nishinokyo, Samaryocho, Nakagyo-ku, Kyoto, 604-8091, Japan. ${ }^{4}$ Department of Pharmacy, Saiseikai-Nakatsu Hospital, 2-10-39, Shibata, Kita-ku, Osaka, 530-0012, Japan. ${ }^{5}$ Department of Oral Health, Kobe Tokiwa Junior College, 2-6-2, Otani-cho, Nagata-ku, Kobe, 653-0838, Japan. ${ }^{6}$ Department of Dental Science for Health Promotion, Hiroshima University Graduate School of Biomedical Sciences, 1 2-3, Kasumi, Minami-ku, Hiroshima, 734-8551, Japan. ${ }^{7}$ Division of Diabetes, Clinical Nutrition and Endocrinology, Kansai Electric Power Hospital, 2-1-7, Fukushima, Fukushima-ku, Osaka, 553-0003, Japan. ${ }^{8}$ Department of Internal Medicine, Kyoto Postal Services Agency Hospital, 109,Nishirokkakucho, Rokkaku-street, Shinmachi, Nakagyo-ku, Kyoto, 604-8798, Japan. ${ }^{9}$ Kyoto Institute of Health Science, Karasumaoike-Higashi, Nakagyo-ku, Kyoto, 6040845, Japan. ${ }^{10}$ Division of Endocrinology and Metabolism, Jichi Medical University, 3311-1, Yakushiji, Shimono-city, Tochigi, 329-0498, Japan.

\section{Authors' contributions}

NW researched data, wrote the manuscript and contributed to discussion, MF wrote the manuscript, contributed to discussion and reviewed the manuscript, AT wrote the manuscript, contributed to discussion and reviewed the manuscript, TO contributed to discussion, YN contributed to discussion, FN contributed to discussion, SA contributed to discussion, YI contributed to discussion, RO contributed to discussion, DY contributed to discussion, YN contributed to discussion and reviewed the manuscript, SN contributed to discussion and reviewed the manuscript. All authors read and approved the final manuscript. 


\section{Competing interests}

The authors declare that they have no competing interests.

Received: 2 May 2011 Accepted: 25 November 2011

Published: 25 November 2011

\section{References}

1. Laniado-Laborin R: Smoking and choronic obstructive pulmonary disease (COPD). Parallel Epidemics of the $21^{\text {st }}$ Century. Int J Environ Res Public Health 2009, 6:209-224

2. Howard G, Wagenknecht $L E$, Burke $G L$, et al: Cigarette smoking and progression of atherosclerosis: The Athrosclerosis Risk in Communities (ARIC) Study. JAMA 1998, 279:119-124.

3. Taylor RG, Woodman G, Clarke SW: Plasma nicotine concentration and white blood cell counts in smokers. Thorax 1986, 41:407-408.

4. Petrescu F, Voican SC, Silosi I: Tumor necrosis factor-a serum levels in healthy smokers and nonsmokers. Int I Chronic Obstructive Pulmonary Disease 2010, 5:217-222.

5. Brinkman GL, Coates EO Jr: The effect of bronchitis, smoking and occupation on ventilation. Ann Respir Dis 1963, 87:684-693.

6. Miyatake N, Wada J, Kawasaki Y, et al: Relationship between metabolic syndrome and cigarette smoking in the Japanese population. Int Med 2006, 1039-1043

7. Seino Y, Nanjo K, Tajima N, et al: Report of the Committee on the Classification and Diagnostic Criteria of Diabetes Mellitus. Journal of Diabetes Investigation 2010, 1:212-228.

8. Seino Y, Nanjo K, Tajima N, et al: Report of the Committee on the Classification and Diagnostic Criteria of Diabetes Mellitus. Diabetology International 2010, 1:2-20

9. Yatagi T, Nagasaka S, Taniguchi A, et al: Hypoadiponecinemia is associated with visceral fat accumulation and insulin resistance in Japanese men with type 2 diabetes mellitus. Metabolism 2003, 52:1274-1278.

10. Kawasaki Y, Taniguchi A, Fukushima M, et al: Soluble TNF receptors and albuminuria in non-obese Japanese type 2 diabetic patients. Horm Metab Res 2004, 37:617-621.

11. Ohya M, Taniguchi A, Fukushima M, et al: Three measures of tumor necrosis factor a activity and insulin resistance in nonobese Japanese type 2 diabetic patients. Metabolism 2005, 54:1297-1301.

12. Ohgushi M, Taniguchi A, Fukushima M, et al: Soluble tumor necrosis factor receptor 2 is independently associated with pulse wave velocity in nonobese Japanese patients with type 2 diabetes mellitus. Metabolism 2007, 56:571-577.

13. Taniguchi A, Fukushima M, Kuroe A, et al: Metabolic syndrome, insulin resistance, and atherosclerosis in Japanese type 2 diabetic patients. Metabolism 2007, 56:1099-1103.

14. Matthews D, Hosker J, Rudenski A, et al: Homeostasis model assessment: Insulin resistance and B-cell function from fasting plasma glucose and insulin concentrations in man. Diabetologia 1985, 28:412-419.

15. Fukushima M, Taniguchi A, Sakai M, et al: Homeostasis model assessment as a clinical index of insulin resistance (letter). Diabetes Care 1999, 22:1911-1912

16. Zoppini $G$, Faccini $G$, Muggeo $M$, et al: Elevated plasma levels of soluble receptors of TNF- $a$ and their association with smoking and microvascular complications in young adults with type 1 diabetes. $J$ Clin Endocrinol Metab 2001, 186:3805-3808.

17. Tsatsanis C, Zacharioudaki V, Androulidaki A, et al: Adiponectin induces TNF-alpha and IL-6 in macrophages and promotes tolerance to itself and other pro-inflammatory stimuli. Biochem Bophys Res Commun 2005, 335:1254-1263.

18. Hector J, Schwarzloh B, Goehring J, et al: TNF-alpha alters visfatin and adiponectin levels in human fat. Horm Metab Res 2007, 39:250-255

19. Komiya H, Mori Y, Yokose $T$, et al: Smoking as a risk factor for visceral fat accumulation in Japanese men. Tohoku J Exp Med 2006, 208:123-132.

20. Bostrom $L$, $L$ inder $L E$, Bergstrom J: Smoking and cervicular fluid levels of IL-6 and TNF-a in periodontal disease. J Clin Periodontal 1999, 26:352-357.

21. Nomura $Y$, Taniguchi A, Fukushima $M$, et al: Soluble TNF receptor and periodontal disease in non-obese Japanese type 2 diabetic patients (letter). Horm Metab Res 2006, 38:688-689.

22. Iwamoto $Y$, Nishimura $F$, Soga $Y$, et al: Antimicrobial periodontal treatment decreases $\mathrm{C}$-reactive protein, tumor necrosis factor-alpha, but not adiponectin levels in patients with chronic periodontitis. J

Periodontol 2001, 72:774-778.

23. Kern PA, Ranganathan $\mathrm{S}, \mathrm{Li} \mathrm{C}$, et al: Adipose tissue tumor necrosis factor and interleukin-6 expression in humans obesity and insulin resistance. Am J Physiol Endocrinol Metab 2001, 280:E745-E751.

24. Rauchhaus M, Doehner W, Francis DP, et al: Plasma cytokine parameters and mortality in patients with chronic heart failure. Circulation 2000, 102:3060-3067.

25. Taniguchi A, Fukushima $M, N a k a i ~ Y$, et al: Soluble tumor necrosis factor receptor 1 is strongly and independently associated with serum homocysteine in nonobese Japanese type 2 diabetic patients (letter). Diabetes Care 2006, 29:949-950.

26. Pinto-Sietsma S, Mulder J, Janssen WMT, et al: Smoking is related to albuminuria and abnormal renal function in nondiabetic persons. Ann Intern Med 2000, 133:585-591.

27. Jatoi NA, Jerrard-Dunne P, Feely J, et al: Impact of smoking and smoking cession on arterial stiffness and aortic wave reflection in hypertension. Hypertension 2007, 49:981-985.

doi:10.1186/1617-9625-9-12

Cite this article as: Watanabe et al: Smoking, white blood cell counts, and TNF system activity in Japanese male subjects with normal glucose tolerance. Tobacco Induced Diseases 2011 9:12.

\section{Submit your next manuscript to BioMed Central and take full advantage of:}

- Convenient online submission

- Thorough peer review

- No space constraints or color figure charges

- Immediate publication on acceptance

- Inclusion in PubMed, CAS, Scopus and Google Scholar

- Research which is freely available for redistribution

Submit your manuscript at www.biomedcentral.com/submit
Ciomed Central 